\title{
Přístupy české vzdělávací politiky po roce 1989: Deprofesionalizace učitelství a učitelského vzdělávání?
}

\author{
Vladimíra SpIlková
}

\begin{abstract}
Abstrakt: Príspèvek je věnován kritické reflexi vývoje přistupu české vzdělávací politiky $k$ učitelské profesi a prípravě na ni po roce 1989. Jsou analyzovány relevantni dokumenty vzdèlávaci politiky, legislativni návrhy i reálné zásahy decizni sféry v této oblasti v poslednich 25 letech. $V$ centru pozornosti jsou mezniky ve vývoji a klićové problémy-profesionalizace učitelství a jeji podpora ze strany vzdèlávaci politiky vs. deprofesionalizace, profesni standard jako soubor kličových profesnich kompetencí, které jsou predpokladem ke kvalitnimu zvládání profese v mènícich se nárocich na školni vzděláváni, karierni systém jako prostředek $k$ podpoře profesniho rüstu učitelü, prístupy ke kvalitě učitelského vzdèláváni, mira liberálnosti vzdělávaci politiky v oblasti př́pravy učitelì $v$ kontextu výrazné kurikulárni reformy (akademické svobody na straně jedné a odpovédnost státu za kvalitu vzděláváni a tedy i za kvalitu učitelù na straně druhé), vymezováni rámcových požadavkü na prípravu učitelù ze strany státu, reálné možnosti a meze Akreditačni komise $\check{C} R$ v ovlivňováni kvality vzděláváni na fakultách připravujicich budouci učitele.
\end{abstract}

Kličová slova: vzdělávaci politika, promèny profese v kontextu promèn školního vzdèláváni, profesionalizace a de-profesionalizace učitelství, profesni standard, kvalita učitelského vzdéláváni, fakulty pripravujici učitele, akreditačni komise.

\section{ÚvOD}

Zvyšování kvality/profesionality učitelů, jejich př́ípravného vzdělávání i dalšího profesního rozvoje je $\mathrm{v}$ posledních letech ve vyspělých zemích jednou z klíčových priorit vzdělávací politiky. Tento trend lze sledovat $\mathrm{v}$ mnoha mezinárodních dokumentech Evropské komise, Evropského parlamentu, OECD, ETUCE (European Trade Union Committee for Education),
ATEE (Association for Teacher Education in Europe) aj. (podrobněji Spilková, 2010). Souvisí s výrazně se zvyšujícími nároky na kvalitu školního vzdělávání, což s sebou nese snahu o výraznou profesionalizaci učitelství a zvýšení kvality/ profesionality učitelů.

Profesionalizace učitelství je celosvětově považována za klíčový nástroj vzdělávacích reforem a inovací $\mathrm{v}$ činnosti škol, za základní podmínku úspěchu 
v jejich implementaci. Bývá považována za podmínku ke zkvalitňování práce učitelů $s$ tím, že „klíč ke zlepšení kvality škol do značné míry leží ve zvýšení statusu učitelů, ve zlepšení podmínek učitelství, to znamená $\mathrm{v}$ podpoře profesionalizace učitelství a učitelü“ (Ingersoll \& Alsalam, 1997, s. 1). Ve většině vyspělých zemí lze sledovat snahy (v různých zemích různě intenzivní) o podporu profesionalizačních procesů zevnitř i vně profese.

Cílem studie je kriticky zhodnotit vývoj přístupů české vzdělávací politiky $\mathrm{k}$ učitelské profesi a učitelskému vzdělávání po roce 1989, a to se zvláštním zřetelem $\mathrm{k}$ jejímu vlivu na profesionalizaci, event. deprofesionalizaci učitelství.

\section{KONCEPT PROFESIONALIZACE UČITELSTVÍ}

Je-li na profesionalizaci učitelství kladen tak velký důraz, je zapotřebí tento fenomén alespoň stručně charakterizovat. $\mathrm{V}$ sociologickém pojetí je profesionalizace učitelství cestou, pohybem od tzv. semiprofese ke skutečné, opravdové profesi. Za klíčové znaky skutečných profesí (lékař, právník aj.) jsou považovány: soubor profesních, expertních znalostí a dovedností, které výrazně odlišují profesionála od laika; dlouhá doba speciálního výcviku; smysl pro službu veřejnosti; celoživotní angažovanost a oddanost práci a klientům; etický kodex; existence profesních komor, které udržují „stavovskou“ čest a pečují o profesní etiku; kontrola nad licenčními standardy a požadavky na výkon profese; autonomie $\mathrm{v}$ rozhodování a odpovědnost za výkon činnosti; vysoká úroveň důvěry, autority a sociální prestiže profese, vysoký ekonomický status.

V sociologickém nahlížení na profesionalizaci učitelství lze nalézt také jiné prýistupy, které upozorňují na rozdíly a odlišnosti mezi učitelstvím a již etablovanými profesemi (napřr. Píšová et al., 2011). Tyto př́stupy zdůrazňují, že získání profesionálního statutu je historicko-společenský proces a že vzhledem $\mathrm{k}$ současnému kontextu by učitelství mělo jít ve svém emancipačním úsilí jinou cestou, než je snaha naplňovat všechny formální znaky profese. Za klíčový faktor je považována angažovanost a výrazná aktivita učitelské komunity, to znamená, aby ve všem, co se týká učitelské profese, př́pravy na ni, celoživotního profesního rozvoje apod., silně zazníval hlas této komunity.

$\mathrm{V}$ kontextu výše uvedeného je značný význam pro emancipaci profese připisován existenci profesních sdružení, která zevnitř kontrolují kvalitu, usilují o zlepšení společenského statusu a prestiže, obhajují zájmy př́ílušníků profese proti nekompetentním zásahům zvenčí, např. ze strany decizní sféry, politických stran, zřizovatelů škol, inspekce. Učitelé ve vyspělých zemích realizovali $\mathrm{v}$ rámci emancipačních procesů řadu politických, odborných a organizačních aktivit a postupně se jim dařilo ovlivňovat podstatné otázky týkající se učitelské profese.

$\mathrm{V}$ podpoře profesionalizace učitelství je kladen důraz na široké spektrum specifických profesních, expertních znalostí - professional knowledge (Shulman, 1987; Janík, 2005), které jsou vytvářeny na základě 
soudobé teorie a výsledků výzkumů. Kromě kvalitně položeného základu $\mathrm{v}$ podobě vysokoškolského studia je zdůrazňováno celoživotní profesní učení. Jednou z priorit je systematická reflexe praktických zkušeností, tedy přemýšlení o žácích, procesech i výsledcích učení v širších souvislostech, se snahou hlouběji porozumět pedagogickým jevům, hledat alternativní řešení apod. Činnost učitele by měla být podložena zvnitřněnými profesními znalostmi a přesvědčeními, být promyšlená ve smyslu uvědomění si toho, co a proč dělám, $\mathrm{k}$ jakým cílům směřuji, jak kvalitně zprostředkovávat základy poznání žákům, rozvíjet myšlení a další kvality žákovské osobnosti $s$ ohledem na věková a individuální specifika, jak předcházet neúspěchu a naopak dosahovat maximálního rozvoje individuálních předpokladů žáků apod.

Naznačené reflektivní/přemýšlivé pojetí učitelství (Korthagen et al., 2011), vyžadující systematické profesní znalosti, je opakem intuitivního učitelství, které je často založeno na př́stupech pokusomyl, na tzv. folk pedagogy, tedy lidové, laické pedagogice nezřídka vycházející z „dojmologie“, mýtů, intuitivních představ a nezdůvodněných názorů.

V zemích, kde učitelství ušlo už značný kus cesty k opravdové, expertní profesi, se klade důraz kromě profesních, expertních znalostí také na celoživotní angažovanost propojenou $s$ potřebou celoživotního profesního rozvoje a systematického vzdělávání, na profesní hodnoty (ctnosti), jasně artikulovanou etiku profese. $\mathrm{Z}$ profesních kompetencí zejména na dovednost reflexe a sebereflexe, které jsou považová- ny za podmínku zkvalitňování pedagogické činnosti a celoživotního profesního rozvoje.

Důraz je kladen rovněž na vysokou míru profesní autonomie, posílení autority učitele ve vzdělávacím systému (teacher empowerment). Učitel-profesionál vítá autonomii jako prostor pro odborné rozhodování a uvědomuje si odpovědnost za důsledky vlastních rozhodnutí. Přijímá vysokou míru profesní odpovědnosti, spolu/odpovědnosti za podporu optimálního rozvoje každého žáka, jeho vývojových a individuálních možností, v intencích společenských požadavků a představ o kvalitním vzdělávání (Coolahan, 1993; Pollard, 2001).

Při srovnání současného stavu profesionalizace učitelství v řadě vyspělých zemí se situací v České republice je zřetelně vidět, že u nás učitelství stále setrvává spíše na úrovni semiprofese, respektive v mnoha aspektech směruje $\mathrm{k}$ deprofesionalizaci. Nejsou naplněny klíčové znaky skutečné profese - neexistuje profesní standard, etický kodex, profesní komora. Nedostatečná je míra vnitřně přijaté profesní autonomie a profesní odpovědnosti u většiny učitelů, což má řadu objektivních důvodů. Nejdůležitější z nich je zřejmě skutečnost, že učitelé po mnoho let pracovali v podmínkách modelu tzv. omezené profesionality (restricted profesionalism), který je typický pro vysoce centralizované vzdělávací systémy. Učitelé byli chápáni jako vykonavatelé, realizátoři, spotřebitelé kurikula s minimální profesní autonomií. Profesní autonomie v tvorbě kurikula, přechod od role učitele jako spotřebitele 
kurikula $\mathrm{k}$ roli učitele jako spolutvůrce kurikula, je pro mnoho učitelů vskutku náročným „koperníkovským“ obratem.

Řada výzkumů z posledních let prokazuje nepřipravenost velkého množství učitelů na nové požadavky na vykonávání profese spojené zejména s kurikulární reformou. Někteří autoři hovoří o krizi učitelství, o učitelích jako slabém článku transformačních změn, o jejich neschopnosti vyrovnat se s novými nároky, o neochotě opustit stereotypy $\mathrm{v}$ práci, učit se nové věci, angažovat se $\mathrm{v}$ dlouhodobém procesu vlastní proměny a proměny školy (např. Helus, 2007; Straková \& Spilková et al., 2013, 2014). Konkrétní nedostatky učitelů týkající se kvality výuky i celkového př́stupu $\mathrm{k}$ učitelské profesi jsou považovány za znaky jejich nedostatečné profesionality. $\mathrm{V}$ odborné komunitě lze však sledovat i jiné př́stupy a názory. ̌̌ada autorů upozorňuje na rychle se měnící společenské podmínky související s postmoderní ideologií a neoliberálními trendy, které prredstavují rizikové faktory pro profesionalizaci učitelství (např. Kota, 2010 ; Urbánek, 2013; Štech, 2011, 2013). Co se týče kurikulární reformy, za hlavní problém považují celkový koncept reformy a způsob její implementace, a proto víceméně príznivě hodnotí fakt, že učitelé „slepě“ nepřijali požadované změny (Štech, 2013).

Problematiku profesionalizace učitelství lze zkoumat ve čtyřech základních rovinách - expertní (teoretická, výzkumná, vývojová), vzdělávací politiky, legislativní a praktické (realizační). V tomto textu se zaměříme na rovinu vzdělávací politiky, konkrétně na vývoj přístupů české vzdělávací politiky $\mathrm{k}$ učitelské profesi a prrípravě na ni, a to se zvláštním zřetelem $\mathrm{k}$ jejímu vlivu na profesionalizaci, event. deprofesionalizaci učitelství. V centru pozornosti budou vzhledem $\mathrm{k}$ limitovanému rozsahu prríspěvku pouze vybrané fenomény, které představují v dané oblasti určité milníky.

\section{VÝVOJ PŘíSTUPŮ ČESKÉ}

VZDĚLÁVACÍ POLITIKY K UČITELSKÉ PROFESI A PŘÍPRAVĚ NA NI

\subsection{Devadesátá léta - absence vzdělávací politiky}

Analýza dokumentů vzdělávací politiky a základních koncepčních materiálů $\mathrm{k}$ transformaci školství po roce 1989 z dílny Ministerstvo školství, mládeže a tělovýchovy (MŠMT) s cílem zjistit, jaká pozornost je $\mathrm{v}$ nich věnována učitelské profesi, př́ípravě na ni a celoživotnímu profesnímu rozvoji učitelů, ukazuje, že tato otázka dlouhodobě unikala pozornosti. Většina oficiálních materiálů se k otázkám učitelského vzdělávání explicitně nevyjadřovala nebo jen na úrovni obecných proklamací, např. k prestiži učitele a jeho významu ve školských proměnách, $\mathrm{k}$ základním modelům učitelského vzdělání, $\mathrm{k}$ nutnosti dalšího profesního růstu učitelů apod.

Dokladem tohoto nezájmu je skutečnost, že MŠMT nevytvořilo až do roku 1995 alespoň rámcovou představu př́pravného a dalšího vzdělávání učitelů. Neexistenci základního koncepčního materiálu, který by v základních rysech vymezil systém prrípravy učitelů v České republice, 
označila za závažný problém také akreditační komise, která v letech 1993-1995 prováděla akreditaci pedagogických fakult (Kurzweil, Mikulec \& Vinš, 1995).

Absence vzdělávací politiky $\mathrm{v}$ kombinaci s poměrně vysokou autonomií vysokých škol vedla v oblasti učitelského vzdělávání na fakultách připravujících učitele $\mathrm{k}$ živelnému vývoji. Za pozitivní lze považovat vytvoření prostoru pro hledání a krystalizaci inovací a rozmanitých podob prípravy učitelů „zezdola“, na půdě jednotlivých fakult, či spíše kateder. Přes mnohá pozitiva těchto „svépomocných “ reformních aktivit bez společného koncepčního rámce přinesl živelný vývoj v devadesátých letech mnoho negativních změn. $V$ souvislosti s postavením „učitelských“ fakult $\mathrm{v}$ rámci univerzit vedla liberální politika státu k podceňování významu kvalitního vzdělávání učitelů pro kvalitu vzdělanosti budoucích generací, k zanedbávání, podfinancování a postupně i personálnímu "tunelování “ těchto fakult v rámci některých univerzit. Proces postupného odsávání kapacit, rušení či přesuny pracovišt na nově vznikající fakulty vedl na některých pedagogických fakultách k proměně v jakési „zbytkové “ fakulty hraničící s ohrožením jejich další existence (Urbánek, 2013).

Většina negativních důsledků tohoto vývoje se projevila zejména $\mathrm{v}$ pojetí vzdělávání učitelů pro 2 . stupeň základní školy a školy střední. Na mnoha univerzitních fakultách se objevil tlak na deprofesionalizaci vzdělávání této kategorie, který vyústil ve výrazné omezení jeho teoretické i praktické profesní složky. V oblasti učitelství pro 1. stupeň základní školy byla idea profesionalizace naopak přijata na začátku devadesátých let jako základní východisko změn na všech devíti pedagogických fakultách v ČR.

První rámcový dokument k př́ípravnému i dalšímu vzdělávání učitelů, vytvořený MŠMT, byl zveřejněn $\mathrm{v}$ roce 1995 pod názvem Učitel. Ministerstvo školství ho představilo širší veřejnosti na tiskové konferenci 1. 11. 1995. V něm byla formulována základní strategie MŠMT především ve vazbě na připravované legislativní změny (zákon o vysokém školství, vyhláška o odborné a pedagogické způsobilosti pedagogických pracovníků apod.).

Jako jeden ze základních principů byla zdůrazněna tzv. diverzifikace učitelského vzdělání. Diverzifikace horizontální znamenala, že na prŕpravě učitelů se mohou podílet instituce různého typu - středoškolské, vysoké školy a „vysokoškolské instituty“, jejichž vznik měl umožnit nový zákon o vysokém školství. Vertikální diverzifikace znamenala diferencovanou nabídku studijních programů považovaných za minimální vzdělání pro učitele jednotlivých stupňů škol.

Diverzifikace učitelského vzdělání byla založena na přísném oddělování prrípravy učitelů pro jednotlivé školské stupně z hlediska úrovně i délky studia - středoškolské vzdělání pro učitele mateřské školy, bakalářské studium pro učitele 1.-5.ročníku ZŠ (v prvních verzích, v dalších verzích se už objevuje magisterské studium), magisterské studium pro učitele 6.-9.ročníku základní školy (předmětem úvah bylo i bakalářské studium pro tuto kategorii učitelů), magisterské studium pro učitele středních 
škol (nikoli nebo převážně nikoli na pedagogických fakultách). Hierarchie jednotlivých učitelských kategorií byla posílena tím, že kvalitativně odlišné a vzájemně neprostupné programy jejich vzdělávání byly $\mathrm{v}$ návrzích svěrovány různým institucím (střední pedagogické školy, vyšší školy, vysokoškolské instituty, pedagogické fakulty univerzit, univerzitní odborné fakulty).

Tato koncepce se stala předmětem ostré kritiky odborné veřejnosti, především kvůli úvahám o de-univerzitarizaci, tedy přenesení vzdělávání vybraných kategorií učitelů do mimouniverzitních institucí, a de-profesionalizaci, tedy snížení nároků na kvalitu a délku vzdělávání učitelů. Hlavními argumenty proti navrhované koncepci bylo přeceňování prakticistního zaměření a ztráta spojení s univerzitní vědecko-výzkumnou základnou, které by se v delší časové perspektivě výrazně promítly do kvality učitelské př́ípravy až k možnému propadu na středoškolskou úroveň jakýchsi novodobých učitelských ústavů. Velké rozpaky v odborné veřejnosti způsobil fakt, že státní správa přichází s historicky překonaným řemeslným pojetím profese, degradujícím učitele na „řemeslníka profese“. Tento dokument vzdělávací politiky naštěstí časem upadl v zapomnění, žádná z navržených strategií nebyla uvedena do praxe.

\subsection{Koncepční dokumenty a klíčové aktivity decizní sféry v prvním desetiletí 21 . století}

Zásadním krokem ve vzdělávací politice ve vztahu ke koncipování př́pravného i dalšího vzdělávání učitelů byl Národní program rozvoje vzděláni (2001, dále jen Bílá kniha). V Bílé knize jsou kvalitní učitelé považováni za klíčové aktéry proměny školy a $s$ tím je spojen apel na nutnost proměn $\mathrm{v}$ pojetí učitelské profese, $\mathrm{v}$ pojetí rolí a kompetencí učitele jako východiska pro zásadní změny v koncepci učitelského vzdělávání. Mezi prioritami jsou zdůrazněny nutnost posílení prestiže učitelské profese, zvýšení profesionality učitelů, vytvoření systému kariérového postupu, který by učitele motivoval ke zvyšování kvality práce a k celoživotnímu profesnímu rozvoji.

Za důležitý prostředek ke zvyšování kvality vzdělávání učitelů je v Bílé knize považováno vytvoření profesních standardů, které by byly základním východiskem pro formulování rámcových programů přípravného vzdělávání učitelů i kompasem na cestě dalšího profesního rozvoje. Profesní standard měl vytvořit sjednocující rámec pro velmi diverzifikovaný systém př́ípravného vzdělávání učitelů $\mathrm{v}$ ČR, $\mathrm{v}$ němž na devíti pedagogických a $\mathrm{v}$ dané době více než dvaceti dalších fakultách koexistují modely velmi rozdílné $\mathrm{z}$ hlediska délky, pojetí a struktury studia, z hlediska požadavků na výstupy apod. (napr. Doulík \& Škoda, 2011 ). Profesní standard měl být celostátně platným kritériem pro akreditace vzdělávacích programů v oblasti učitelského vzdělávání i podmínkou pro získání plné kvalifikace.

$\mathrm{V}$ návaznosti na Bílou knihu byl $\mathrm{v}$ rámci grantu MŠMT zpracován v letech 2000-2001 projekt Podpora práce učiteli (nositelem projektu byla Pedagogická fakulta Univerzity Karlovy). Jedním z jeho 
nejdůležitějších výstupů byl pokus o formulování profesních standardů v podobě klícových kompetencí učitele (Walterová, 2004; Vašutová, 2004; Spilková et al., 2004; Urbánek, 2005). Přestože MŠMT práce na tvorbě profesního standardu zadalo a výsledky verbálně podpořilo, přestože byl návrh široce diskutován odbornou veřejností a získal podporu, dále se s ním už nepracovalo.

Trvalo další tř̌i roky, než došlo k oživení diskusí na toto téma. Od počátku roku 2004 začalo z iniciativy MŠMT, zejména jeho náměstka pro vysoké školy P. Koláře, pracovat grémium pro problematiku učitelského studia na vysokých školách. Více než desetičlenná skupina byla složena ze zástupců MŠMT i vysokoškolské reprezentace (dva děkani pedagogických fakult, předseda Rady vysokých škol, člen Akreditační komise, prorektor Univerzity Karlovy, dva významní experti na danou problematiku). Činnost grémia byla zaměřena na vytvoření minimálních standardů učitelství, které by MŠMT vydalo formou vyhlášky $\mathrm{v}$ souvislosti $\mathrm{s}$ novými právními normami, a obecného podkladu o podobě učitelského studia. Tyto dokumenty se měly stát základním materiálem pro Akreditační komisi a vysoké školy. Začátkem roku 2005 byl zveřejněn materiál Koncepce pregraduálni prípravy učitelì základnich a strednich škol, který vytvořilo grémium a redakčně upravil J. Mareš (Mareš \& Stuchlíková, 2011).

Hned v úvodu je konstatováno, že současný stav, kdy pojetí, obsah, rozsah a požadavky na výstup učitelského vzdělávání jsou zcela v kompetenci vysokých škol, je nadále neudržitelný. Jsou zde definovány rámcové požadavky na podobu učitelského vzdělávání, aby garantovaly profesní připravenost absolventů studia učitelství, a přitom ponechaly vysokým školám, fakultám i katedrám dostatek prostoru pro konkretizaci a průběžné inovace. Byly navrženy minimální standardy pro učitelskou př́pravu $\mathrm{v}$ podobě čtyř závazných složek učitelské přípravy a jejich vzájemných proporcí (vyjádřených $\mathrm{v}$ procentech z celkové hodinové dotace). Stanovení minimální dotace pro pedagogicko-psychologickou složku ve výši $20 \%$ a pro pedagogickou praxi ve výši $10 \%$ znamenalo výrazné posílení profesionalizace učitelské přípravy. Po letech velmi liberálního př́ístupu vzdělávací politiky $\mathrm{k}$ učitelskému vzdělávání a kvalifikačním požadavkům pro vstup do profese představovaly minimální standardy významný př́slib ke zlepšení situace ve smyslu podpory procesů profesionalizace. Předpokládalo se, že práce budou pokračovat vymezením klíčových kompetencí učitele jako výstupů prípravy a definováním základního obsahu učitelské př́ípravy (předměty, moduly, témata, jež musí studijní program obsahovat).

Slibný vývoj byl narušen sílící kritikou akademických funkcionářu $\mathrm{z}$ některých univerzitních pracovišt', které vedle pedagogických fakult také pripravují učitele, zejména z př́rodovědeckých a filozofických fakult. Byl zpochybňován požadovaný - podle jejich názoru - př́lilš vysoký podíl profesní složky v kurikulu učitelského studia. Důsledkem snah o oslabení vlivu standardů byla změna - ze závazné 
normy pro koncipování studijních programů učitelství se stala norma doporučená. $\mathrm{V}$ této situaci pak Akreditační komise, respektive pracovní skupina pro pedagogiku, psychologii a kinantropologii, ztrácela vliv na kvalitu učitelského vzdělávání, nástroj k posuzování, zda studijní programy připravují budoucí učitele na kvalitní a kompetentní výkon profese $\mathrm{v}$ podmínkách zvyšujících se nároků na školní vzdělávání. To posílilo trend $\mathrm{k}$ nežádoucí deprofesionalizaci učitelského vzdělávání $\mathrm{v}$ př́ípadě učitelství pro 2 . stupeň základních škol a školy střední. V posuzování studijních programů začala převládat váha jiných kritérií než obsahových a koncepčních, napřr. personální zajištění výuky habilitovanými pracovníky. Tato skutečnost vedla některé fakulty $\mathrm{k}$ obcházení tohoto požadavku, zejména fiktivním zaměstnáváním docentů a profesorů.

Dalším impulsem vzdělávací politiky $\mathrm{v}$ oblasti př́pravy učitelů byl tlak MŠMT na restrukturalizaci studia učitelství v souvislosti se vstupem ČR do EU a s tzv. Boloňskou deklarací. Pod silným mocenským tlakem ze strany vzdělávací politiky doprovázeným ekonomickými "donucovacími“" prostředky jako první „kapitulovala“ Pedagogická fakulta MU v Brně, která pod nátlakem tehdejš́ího rektora Zlatušky podává začátkem roku 2003 žádost o akreditaci strukturovaného studia u všech typů učitelství. Brzy ji následuje další fakulta, PedF ZČU Plzeň. Pochybnosti o vhodnosti strukturovaného studia pro obor učitelství včetně argumentace, proč a v čem to může přinést závažné problémy, zůstaly nevyslyšeny (Spilková et al., 2004; Urbánek, 2005, 2006; Urbánek, 2013; Štech, 2011; Mareš \& Stuchlíková, 2011). Př́iběh politicky, direktivně prosazeného strukturovaného studia učitelství, bez odborné diskuze a za ignorování věcných argumentů, je ukázkovým př́kladem destruktivního vlivu vzdělávací politiky na profesionalizaci učitelství a kvalitu učitelského vzdělávání. Zde je třeba zmínit odvahu Pedagogické fakulty JČU v Českých Budějovicích, která se několikrát pokusila předložit návrh na akreditaci nestrukturovaného studia učitelství, bohužel však bez úspěchu.

Politickému tlaku na strukturaci studia odolalo jen učitelství pro primární vzdělávání (učitelství pro 1 . stupeň ZŠ). Důležitou roli zde hrála rychlá „mobilizace" odborné veřejnosti a spolupráce odborníků z pedagogických fakult při formulování stanovisek zpochybňujících vhodnost a zdůvodněnost těchto záměrů. Rozhodující vliv však měla Akreditační komise vlády ČR, respektive pracovní skupina pro pedagogiku, psychologii a kinantropologii, která podpořila argumenty o nevhodnosti změny struktury studia pro tuto kategorii učitelů $s$ tím, že by byla př́iliš radikálním zásahem do již inovovaného pojetí jejich přípravy.

Hlavní argument spočíval $\mathrm{v}$ potřebě integrace vyplývající z multidisciplinarity studia. Bylo respektováno, že specifické pojetí profesní i oborové prŕípravy vyžaduje integrovaný, nestrukturovaný model studia, který umožňuje průběžnou interakci mezi jednotlivými prvky kurikula v průběhu celého studia a dlouhodobý výcvik některých profesních dovedností. 
Argumenty o nevhodnosti strukturace tohoto studijního oboru, která by vedla $s$ vysokou pravděpodobní $\mathrm{k}$ výraznému poklesu kvality učitelské př́pravy, byly uznány a tím se podařilo (prostřednictvím akreditační komise) zablokovat tlak na nucené strukturování (Spilková \& Hejlová, 2010). Zajímavé je srovnání se situací na Slovensku, kde pod politickým tlakem došlo $\mathrm{k}$ plošné strukturaci všech studijních programů učitelství, což je v posledních letech předmětem silné kritiky většiny akademické reprezentace (Kosová in Spilková \& Hejlová, 2010).

$\mathrm{V}$ případě studia učitelství pro 1 . stupeň ZŠ př́ináší tlak na strukturaci také výrazné oživení snah degradovat toto studium na bakalářskou úroveň, a to za podpory nemalé části politiků a MŠMT. Tento pokus byl již několikátým $\mathrm{v}$ řadě za posledních 15 let. $V$ tomto smyslu má zásadní význam zákon č. 563/2004 Sb., o pedagogických pracovnících, $v$ němž je závazně vymezeno magisterské studium jako podmínka pro uznání učitelské kvalifikace. (Je to především zásluhou tehdejšího poradce ministryně školství J. Kotáska, který svedl o prosazení tohoto požadavku do zákona doslova boj.)

V následujících letech vydává vzdělávací politika další znepokojivé signály v podobě návrhů novel výše uvedeného zákona (2007, 2009), které by umožnily působení středoškolsky vzdělaných učitelů jako plně kvalifikovaných v základních školách. Návrh novely zákona z roku 2007 je dokonce prosazován poslanci vládní strany pod vedením předsedy školského výboru Parlamentu ČR W. Bartoše. Tyto návrhy měly doslova destrukční charakter z hlediska profesionalizace učitelství a představovaly nebezpečný útok na kvalitu školního vzdělávání. Odborná veřejnost poukazovala na to, že je politicky nezodpovědné navrhovat radikální snížení nároků na vzdělání učitelů $\mathrm{v}$ době zahájení zásadní kurikulární reformy v základním školství, která s sebou naopak nese zvýšené požadavky na učitele a jejich profesní kompetence.

Realizované legislativní kroky, novely zákona z roku 2006 a 2011, lze považovat za jistou rezignaci vzdělávací politiky na podporu kvality učitelů ve smyslu zvyšování jejich profesionality. Prvně zmiňovaná novela zmírňuje nároky na odbornou kvalifikaci u učitelů starších 50 let, druhá zmírňuje požadavky na odbornou kvalifikovanost učitelů jednotlivých stupňů škol. $V$ kontextu těchto snah je třeba také zmínit Závěrečnou zprávu Národní ekonomické rady vlády $(\mathrm{NERV})^{1} \mathrm{z}$ roku 2011, v níž je navrhováno, aby se snížil zákonný požadavek na kvalifikaci pro učitele 2. stupně ZŠ na bakalářskou úroveň (magisterské studium mělo být ponecháno pouze pro učitele 1 . stupně $Z \check{S}$ a ředitele).

$\mathrm{K}$ důležitému vývoji dochází také $\mathrm{v}$ další oblasti. Ve druhé polovině prvního desetiletí zesiluje názor, že je nutné explicitně definovat kvalitu učitele a legislativně ukotvit profesní standard jako

\footnotetext{
${ }^{1}$ Závèrečná zpráva podskupin Národni ekonomické rady vlády pro konkurenceschopnost a podporu podnikání. Kapitola III. - Vzdělanost (2011). Dostupné z http://www.vlada.cz/assets/media-centrum/aktualne/NERV_kap03.pdf
} 
normu, která na základě struktury profesních činností, povinností a odpovědností stanoví profesní kompetence potřebné pro kvalitní, standardní výkon profese (Spilková \& Vašutová, 2008). Po zhruba deseti letech liberální vzdělávací politiky a důrazu na autonomii učitelské profese se začíná prosazovat trend ke standardizaci profese.

\subsection{Oživení snah o standardizaci profese}

Profesní standard je chápán jako důležitý nástroj $\mathrm{k}$ výraznější profesionalizaci učitelů, která by měla také pomoci v realizaci kurikulární reformy. Zejména problémy $s$ připraveností učitelů a ředitelů na nové požadavky spojené s kurikulární reformou výrazně zesílily potřebu jasně definovat nové role a profesní kompetence učitelů, které jsou předpokladem kvalitního vykonávání profese ve změněných podmínkách a nárocích na kvalitní vzdělávání (Vašutová, 2004; Kratochvílová, 2007; Simonová \& Straková, 2005).

Výrazem oživení zájmu vzdělávací politiky o téma kvality učitele a učitelské vzdělávání bylo zřízení expertní skupiny $\mathrm{k}$ tvorbě profesního standardu. MŠMT ji vytvořilo v roce 2008 ze zástupců akademické sféry, pedagogického výzkumu a školské praxe. Na konci roku byl předložen rámcový dokument Standard kvality profese učitele, který nabídl k diskuzi zejména určitou „filozofii" standardu, jeho smysl, cíle a funkce, dále jako př́klad jednu z možných verzí standardu v podobě výčtu profesních činností důležitých pro kvalitní výkon profese (Spilková \& Tomková, 2010).
$\mathrm{Za}$ jednu $\mathrm{z}$ nejdůležitějších funkcí profesního standardu byly považovány funkce sjednocujícího rámce pro formulování profilu absolventa studia učitelství na fakultách prípravujících učitele a jako východiska pro proměny pregraduální prrípravy učitelů a systému jejich dalšího vzdělávání. Standard měl vytvořit tlak na profesionalizaci studia učitelství (zejména $\mathrm{v}$ prrípravném vzdělávání učitelů 2. stupně základních škol a škol středních), na proměnu složek kurikula s důrazem na profesní príípravu, na definování klíčových a nepominutelných obsahů výuky. $V$ př́ípadě dalšího vzdělávání učitelů, $\mathrm{v}$ němž vládl a dosud vládne velmi liberální přístup, kdy na trhu se vzděláváním v podstatě „kdokoli nabízí cokoli“, mělo jít o tlak na cílenější zaměření vzdělávací nabídky směrem $k$ lepší připravenosti učitelů na měnící se nároky na kvalitu školního vzdělávání.

Od března do července 2009 probíhala veřejná diskuze na webu MŠMT, do které se zapojily pedagogické asociace, především Stálá konference asociací ve vzdělávání (SKAV) a Asociace profese učitelství (APU), dále fakulty připravující učitele, další relevantní instituce i jednotlivci. V internetové diskuzi vyjádřilo své názory více než 1500 učitelů a ředitelů mateřských, základních a středních škol, 24 asociací a 20 fakult připravujících učitele. $\mathrm{V}$ průběhu diskuze byly vypracovány dvě podrobné analýzy názorů a návrhů diskutujících subjektů.

Tvorba profesního standardu byla zvažována $\mathrm{v}$ širších kontextech měnících se požadavků na pojetí učitelství v souvis- 
losti s probíhající kurikulární reformou, ve vztahu ke vzdělávání učitelů a jejich dalšímu profesnímu rozvoji, kariérnímu řádu a v neposlední řadě také ve vazbě na požadavky na zabezpečenost profese a vytvoření podmínek pro její kvalitní vykonávání.

Fakulty připravující učitele a některé asociace (zejména APU a SKAV) publikovaly podpůrná stanoviska $\mathrm{k}$ tvorbě standardu a analyzovaly možnosti, které by existence standardu pro učitele otevřela, a také identifikovaly rizika, která $s$ sebou standard nese. Převažoval názor, že profesní standard představuje šanci formulovat (a ovlivnit, pokud bude tvořen „zdola“ za účasti profesní komunity) představy o tom, kdo je to kvalitní učitel v současné době, jak má být vzdělán, aby zvládl zvyšující se požadavky na svou práci, jak má být kvalita výkonu profese ohodnocena apod. Standard byl považován za nástroj $\mathrm{k}$ tomu, aby se učitelé stávali většími profesionály. Měl být prostředkem k profesnímu rozvoji učitele, měl ho motivovat a ukazovat cestu ke zkvalitňování činnosti. Výrazně zazníval názor, že by vzdělávací politika a decizní sféra neměla spoléhat pouze na vnitřní motivaci učitelů, na to, že vnímají svoji profesi jako poslání, že mají své povolání rádi, a proto usilují o kvalitu své práce. Bylo formulováno přesvědčení, že společnost, která (ne)dokáže finančně ocenit dobrého učitele, tím současně vyjadřuje (ne)úctu ke kvalitě vykonávání učitelské profese.

Současně byla pojmenována i rizika. Jedním z největších je zavedení standardu bez vytvoření nutných podmínek. Za klí- čovou podmínku bylo považováno, aby se podpora kvality učitelů a učitelského vzdělávání stala skutečnou (nejen proklamovanou) prioritou státní vzdělávací politiky. Jako konkrétní výraz této priority byla chápána systémová podpora učitelů a učitelského vzdělávání, zejména vytvořením ekonomických a legislativních podmínek, které jsou nutné $\mathrm{k}$ zajištění požadované kvality výkonu učitelské profese, a to jak ve školách, tak v institucích připravujících učitele.

Byl formulován požadavek, aby byla tvorba a zavádění standardu $\mathrm{v}$ souladu $s$ dalšími opatřeními vzdělávací politiky (např. koncepce přípravného vzdělávání učitelů - role Akreditační komise při posuzování programů studia učitelství, systém dalšího vzdělávání pedagogických pracovníků, koncepce hodnocení České školní inspekce, podpora profesního růstu, kariérní řád). Bylo zdůrazněno, že standard musí být vyvíjen seriózním způsobem, zejm. za podstatného zapojení odborné i širší veřejnosti. Objevila se obava $\mathrm{z}$ formalismu a byrokratizace procesu související s chybami, které udělalo MŠMT při zavádění kurikulární reformy.

Slibně nastartovaný proces tvorby profesního standardu byl z iniciativy MŠMT na konci července 2009 přrerušen, bez vysvětlení a zdůvodnění, ve chvíli, kdy se podařilo překonat počáteční nedůvěru a do diskuze se zapojoval stále širší okruh odborné veřejnosti. $\mathrm{Na}$ podzim roku 2009 vykrystalizovala nejasná situace kolem přerušení práce na Standardu do rozhodnutí pokračovat $\mathrm{v}$ jeho tvorbě „zdola“ na půdě profesních asociací a fa- 
kult připravujících učitele. Vůdčí role se ujala Asociace profese učitelství a nabídla vytvoření platformy pro další spolupráci. $\mathrm{Na}$ začátku roku 2010 byl publikován Podkladový materiál pro tvorbu standardu kvality profese učitele, který byl vytvořen už mimo projekt MŠMT, sice na základě původního návrhu, ale $s$ výrazným využitím analýzy veřejné diskuze (Učitelské noviny, 2010, č. 12). Materiál obsahuje jak základní východiska $\mathrm{k}$ tvorbě standardu, tak také návrh struktury standardu vymezující základní oblasti profesních činností a návrhy kritérií $\mathrm{k}$ hodnocení úrovně profesních kompetencí učitelů.

Práce na standardu pokračovala ve vazbě na další projekty, a to zejména na národní projekt Cesta ke kvalitě pod gescí MŠMT, $\mathrm{v}$ jehož rámci byl zpracován a pilotně ověrován Rámec profesnich kvalit učitele, který byl podkladem $\mathrm{k}$ tvorbě nástrojů $\mathrm{k}$ sebehodnocení a hodnocení kvality učitele. Tvorba Rámce profesních kvalit navazovala na koncepci rozpracovaného Standardu kvality profese učitele $s$ využitím analýzy zahraniční př́istupů $\mathrm{k}$ formulování profesních standardů ve vybraných evropských zemích i v zámoří (Spilková \& Tomková, 2010; Spilková, 2010; Tomková, 2012).

Mnohaleté snahy o vytvoření profesního standardu pokračovaly od roku 2012 do roku 2015 v rámci dalšího národního projektu v gesci MŠMT Kariérni systém. Projekt byl výrazně poznamenán problematickou výchozí koncepcí a nedostatečnou kompetentností hlavního řsšitelského pracoviště. Přestože byly diskutabilní návrhy řešení některých klíčových otázek průběžně kritizovány, byl projekt $\mathrm{v}$ průbě- hu roku 2015 dokončen v intencích problematické koncepce. Výstupy projektu - jak koncepce kariérního systému, tak formulace profesního standardu - byly podrobeny $\mathrm{v}$ odborné veřejnosti kritické reflexi, zejména $\mathrm{v}$ širším kontextu evropských trendů v této oblasti (Janík, Spilková \& Píšová, 2014a, 2014b; Rýdl, 2014).

Se změnou ministra školství došlo k obratu, namísto plánované implementace kariérního systému $\mathrm{v}$ pojetí vytvořeném $\mathrm{v}$ rámci projektu byl vytvořen prostor pro kritickou analýzu navrhovaného kariérního systému a pro hledání alternativních variant řešení. Zavedení kariérního systému zůstává $\mathrm{v}$ centru pozornosti, je považováno za jednu z priorit významného dokumentu Strategie vzdělávaci politiky České republiky do roku 2020.

\subsection{Problém nekvalifikovaných učitelù}

V roce 2014 řeší MŠMT „časovanou bombu" v podobě dlouhodobě neřešeného problému působení značného množství nekvalifikovaných učitelů na základních školách (Spilková \& Wildová, 2014). Analytická zpráva z mimoŕádného šetrené o nekvalifikovaných pedagogických pracovnich, v níž jsou podrobně uvedeny výsledky šetření realizovaného v únoru 2014, přináší údaje o celkovém počtu 11090 učitelů bez odborné kvalifikace pro př́ímou pedagogickou činnost, tj. $8,2 \%$. Po přepočtení na plné úvazky se jedná o 8380 učitelů, tj. 6,4\%. Největší počet nekvalifikovaných učitelů je na středních školách (téměř 5400 učitelů, po přepočtení na plné 
úvazky 4500 učitelů), dále na 1. stupni ZŠ (téměř 5100 učitelů, 3300 - plné úvazky), na 2. stupni ZŠ (zhruba 4 300, 3000 - plné úvazky) a v mateřských školách (3500 učitelů, téměř 3000 - plné úvazky).

Naléhavost problému vyprovokovala zájem širší veřejnosti, učitelů, rodičů, profesních asociací, odborů, který byl podporován výraznou mediální kampaní. $\mathrm{Na}$ konci května 2014 byl do Poslanecké sněmovny předložen Vládní návrh novely zákona č. 563/2004 Sb., o pedagogických pracovnících, který pro vymezené př́ípady upravuje předpoklad odborné kvalifikace a upravuje možnost dalšího výkonu pedagogické činnosti některým osobám, které odbornou kvalifikaci nezískaly. Novela zákona č. 197/2014 Sb. umožňuje s účinností od 1. ledna 2015 vykonávat prrímou pedagogickou činnost vybraným skupinám pedagogických pracovníkủ bez odborné kvalifikace.

Novela dává řediteli školy pravomoc "písemně uznat předpoklad odborné kvalifikace" u pracovníka pracujícího na základní či stř̌ední škole na částečný úvazek (max. poloviční), který je „výkonným umělcem, výtvarným umělcem, uznávaným odborníkem v oboru“ (pro výuku předmětu uměleckého nebo odborného zaměření), trenérem. Výjimka z požadavku odborné kvalifikace se týká také výuky cizích jazyků., „Pedagogický pracovník, pro kterého je prŕslušný cizí jazyk rodným jazykem nebo který jej ovládá na úrovni rodného jazyka, splňuje předpoklad odborné kvalifikace pro výuku konverzace v tomto cizím jazyce, získal-li alespoň střední vzdělání s maturitou, nebo pro výuku tohoto cizího jazyka, získal-li vysokoškolské vzdělání.“ Další „hájenou“ skupinou jsou učitelé, kteří dosáhnou k 1. 1.2015 alespoň 55 let věku a 20 let prrímé pedagogické činnosti. Novela umožní školám zaměstnávat nekvalifikované pedagogické pracovníky, pokud prokáží, že nemohou zajistit výchovu a vzdělávání pracovníkem $s$ odbornou kvalifikací.

Novela se stává předmětem kritiky, a to $\mathrm{z}$ opačných úhlů pohledu. Pro jedny je prř́liš „tvrdá“ (zejména někteři ředitelé a učitelé silně kritizují, že ze škol budou muset kvůli zpř́sněným kvalifikačním požadavkům odejít i kvalitní učitelé), pro jiné př́liliš „měkká“, nebot umožňuje řadu výjimek a svou vágností v některých aspektech připouští různorodý výklad. Uved'me př́klady: jak chápat nově zavedenou kategorii „uznávaný odborník“, jak se to bude prokazovat; co to znamená, že učitel ovládá cizí jazyk na úrovni rodného jazyka - kdo a jak to bude posuzovat; jak bude ředitel prokazovat, že nemohl pedagogickou činnost zajistit pracovníkem s odbornou kvalifikací; proč pro nižší úvazek kvalifikaci učitel mít nemusí a pro vyšší ano, co, když si rozšírí úvazek nad 0,5 - ztratí „kvalifikaci“? Za jeden z nejzávažnějších problémů a rizik je považováno přenesení odpovědnosti za kvalitu učitelů a jejich kvalifikovanost ze strany státu a institucí připravujících učitele (garance Akreditační komise ČR) na ředitele škol.

Kromě o rok později schválené novely, zákona č. 379/2015 Sb., o pedagogických pracovnících, která řeší některé spíše dílčí otázky (napřr. speciální pravidla pro uzaví- 
rání pracovních poměrů s pedagogickými pracovníky na dobu určitou, či získání odborné kvalifikace učitelů předmětů uměleckého zaměření), předkládá MŠMT na začátku roku 2016 další návrh novely zákona o pedagogických pracovnících, který nově upravuje kariérní systém učitelů. Definuje tř̌i kariérní stupně a podmínky pro postup kariérním systémem, nastavuje podobu atestačního řízení pro dosažení vyšších kariérních stupňủ a rámcově vymezuje podobu adaptačního období prvních dvou let od nástupu do praxe. Základem nového kariérního systému má být trrístupňový standard učitele.

Významným dokumentem $\mathrm{z}$ hlediska vlivu vzdělávací politiky na kvalitu vzdělávání učitelů bylo vytvoření Rámcové koncepce prípravného vzděláváni učitelì základnich a strednich škol v roce 2015. Po rozsáhlé odborné diskuzi a projednání s MŠMT se stal oficiálním dokumentem, který formuluje standard prŕpravného vzdělávání učitelů $\mathrm{v}$ podobě základních požadavků na kurikulum. Nabízí se však otázka po kontinuitě, nebot Akreditační komise vlády ČR končí k 31. srpnu 2016 po 25 letech svoji činnost. Od 1. záŕí bude nahrazena Národním akreditačním úřadem, jehož činnost by měla přinést zásadní změny. Od akreditace studijních programů se přejde $\mathrm{k}$ institucionálním akreditacím (akreditace vysokých škol jako celku) na dobu 10 let a vejich rámci $\mathrm{k}$ akreditacím oblastí vzdělávání. Vysoké školy by si pak jednotlivé studijní obory vypisovaly samy. Je těžké $\mathrm{v}$ tuto chvíli předvídat, co tak zásadní změna přinese v realitě vzdělávání učitelů.

\section{ZÁVĚR}

Cílem prríspěvku byla kritická reflexe př́stupů české vzdělávací politiky $\mathrm{k}$ podpoře učitelské profese, kvality jejího vykonávání a $\mathrm{k}$ podpoře učitelského vzdělávání a celoživotního profesního rozvoje učitelů. Pokusíme se shrnout klíčové záměry i reálné kroky vzdělávací politiky $\mathrm{v}$ této oblasti po roce 1989 a to zejména vzhledem $\mathrm{k}$ podpoře profesionalizace učitelství a učitelského vzdělávání ze strany vzdělávací politiky.

Témata kvality učitelů a podpory učitelského vzdělávání se nikdy (až na vzácné výjimky) po roce 1989 nedostala mezi priority vzdělávací politiky. Naopak patřila $\mathrm{k}$ tématům dlouhodobě neřešeným a opomíjeným, pokud se někdy dostala do centra pozornosti, pak převážně v proklamativní poloze.

Vzdělávací politika většinou jen $\mathrm{v}$ obecné poloze zdůrazňovala důležitost učitelů $\mathrm{v}$ proměnách školství, nutnost proměn jejich vzdělávání ve smyslu výrazné profesionalizace. Konkrétními činy a kroky však decizní sféra spíše přispívala $\mathrm{k}$ procesům opačným - opakovaným zpochybňováním profesionality a požadavků na kvalifikaci učitelů $-\mathrm{k}$ deprofesionalizaci. $S$ výjimkou např. ustavení Akreditační komise, snah o vytvoření profesního standardu (který však nedokázala decizní sféra dovést ani po 15 letech do zdárného konce), vytvoření konstituování grémia pro učitelské vzdělání (jehož výsledky však nedokázalo MŠMT dostatečně zaštítit a prosazovat jako závaznou normu) a zákona z roku 2004 o pedagogických pra- 
covnících měla většina aktivit, či mnohdy spíše nečinnosti decizní sféry destrukční vliv na verbálně proklamovaný, ale v realitě zcela zanedbávaný proces podpory profesionalizace učitelství a učitelského vzdělávání. $V$ těchto negativních trendech hrají roli také další aktéri, kteří někdy cíleně, jindy nevědomky snižují profesionalitu učitelů a zpochybňují smysl formálního učitelského vzdělávání (např. Scio, 2013).

Ze strany decizní sféry dlouhodobě chybí především snaha o vytvoření systému podmínek nutných $\mathrm{k}$ zabezpečení kvality vykonávání učitelské profese, snaha zvrátit některé negativní trendy - např. celkové podfinancování, nezájem mladých a schopných lidí o učitelství, stárnutí učitelských sborů, vysoká feminizace, nedostatek motivace pro profesní růst, absence péče o začínající učitele (Urbánek, 2005).

Výrazným vyjádřením nedostatečného zájmu vzdělávací politiky o kvalitu učitelského vzdělávání jsou finanční podmínky, které jsou pro př́ípravu učitelů na fakultách vytvořeny. Dlouhodobé podfinancování vysokého školství, zejména humanitních oborů a učitelského studia zvláště (viz „nespravedlive““ stanovené koeficienty na studenty různých oborů) vyústily do současného stavu, který zásadním způsobem ohrožuje kvalitu výuky. Finanční nouze v celostátním měřítku nastartovala trendy, které jsou v prrímém rozporu s pojetím kvalitní př́pravy učitelů i s požadavky školské praxe (tlak na masovost výuky, tedy přednáškové formy a seminární výuku s velkými počty studentů, omezování interaktivních způsobů a výcvikových forem výuky, které jsou nutné k rozvoji po- třebných profesních kompetencí učitelů, apod.). Za této situace je obtížné udržet stávající kvalitu studijních programů, o jejím zvyšování bez vytvoření adekvátních finančních podmínek nemůže být řeč.

Managementy fakult připravujících učitele jsou ekonomickými tlaky nuceny k sebezáchovnému jednání, ekonomické ukazatele se stávají prioritními se snahou udržet fungování fakulty jako celku. Tyto strategie mají však své hranice - viz postupné finanční zbídačování např̀. PedF ZČU v Plzni vedoucí $\mathrm{k}$ odchodu pracovníků $s$ důsledkem značné redukce akreditovaných programů nebo př́pady „vytunelovaných" (v rámci univerzit či soukromých škol) pedagogických fakult, např. v Ústí nad Labem. Podobné negativní trendy spojené s chronickým podfinancováním lze sledovat i na jiných pedagogických fakultách. $\mathrm{V}$ tomto roce napr. došlo $\mathrm{k}$ alarmující situaci (která nemá v rámci pedagogických fakult obdoby), kdy na PedF UK v Praze vedení fakulty zevnitř zablokovalo podání akreditace výrazně inovovaného studijního programu učitelství pro 1. stupeň ZŠ (do něhož byly zařazeny nové obsahy i formy výuky, které byly výzkumně ověřované $\mathrm{v}$ průběhu posledních 10 let). Důvodem byla (údajně) zvýšená finanční náročnost nově navrhovaného studijního programu, což vyústilo v nepřijatelný tlak na převádění seminární výuky na přednášky, což je zcela $v$ rozporu se současnými nároky na kvalitní vzdělávání učitelů. Tyto destrukční tendence vedou autorku tohoto textu po více než dvaceti letech péče o kvalitu studijního programu (garantku stávajícího studijní- 
ho programu) $\mathrm{k}$ rezignaci a odchodu $\mathrm{z}$ fakulty. Uvedený př́pad je jedním z mnoha, které dokladují, jak je situace v učitelském vzdělávání vážná, jak tristní finanční podmínky pedagogických fakult zásadním způsobem ohrožují kvalitu výuky budoucích učitelů.

Z výše uvedených vývojových trendů je zřejmé, že je nejvyšší čas, aby se vzdělávací politika a decizní sféra probudila z dosavadní letargie, nezájmu, nekoncepčnosti a nečinnosti a podnikla rozhodné kroky $\mathrm{k}$ podpoře kvalitního učitelského vzdělávání. Je nutné zmírnit mnohaletý dluh $v$ této oblasti a neprodleně nastartovat procesy, které zastaví probíhající deprofesionalizaci učitelství a tlaky na snižování kvality učitelského vzdělávání, což je $v$ rozporu s trendy ve většině vyspělých zemí.

\section{Literatura}

Analytická zpráva z mimořádného šetření o nekvalifikovaných pedagogických pracovnících (2014). Dostupné $\mathrm{z}$ www.psp.cz/sqw/text/orig2.sqw?idd=99425

Coolahan, J. (Ed.) (1993). Teacher education in the nineties: Towards a new coherence. Papers from the 15th Annual Conference of ATEE. Limerick: College of Education.

Doulík, P., \& Škoda, J. (2011). Hledání kritérií kvality pedagogických fakult. Pedagogika, 61(4), 396-408.

Helus, Z. (2007). Učitelství - rozporuplné povolání pod tlakem nových společenských nároků. Pedagogika, 57(3), 349-363.

Ingersoll, R., \& Alsalam, N. (1997). Teacher professionalization and teacher commitment: a multilevel analysis, SASS. Washington, DC: Statistical analysis report (National Center for Education Statistics).

Janík, T. (2005). Znalost jako kličová kategorie učitelského vzdèlávání. Brno: Paido.

Janík, T., Spilková,V., \& Píšová, M. (2014a). Standard a kariérní systém učitele: problémy předložené koncepce v širších souvislostech. Pedagogická orientace, 24(2), 259-274.

Janík, T., Píšová, M., \& Spilková, V. (2014b). Standardy v učitelské profesi: zahraniční přístupy a pokus o jejich zhodnocení. Orbis scholae, 8(3), 133-158.

Korthagen, F., et al. (2011). Jak spojit praxi s teorii: Didaktika realistického vzděláváni učitelü. Brno: Paido.

Kota, J. (2010). Vybrané problémy profesionalizace učitelů v postmoderní době. In H. Krykorková, R. Váňová et al. Učitel v současné škole (s. 57-76). Praha: FF UK.

Kratochvílová, J. (2007). Učitelé škol v nové roli „tvưrcư šk šolního kurikula. Orbis scholae, 1(1), 101-110. Kurzweil, J., Mikulec, J., \& Vinš, V. (1995). Akreditace pedagogických fakult. Alma mater, 5-6, 256-263.

Mareš, J., \& Stuchlíková, I. (2011). Pedagogické fakulty z pohledu Akreditační komise vlády. Pedagogika, 64(4), 383-395.

MŠMT (1995). Učitel. Dostupné z www.ucitelske-listy.cz/2016/03/jana-hruba-dokumenty-106-navrh-programu.html 
MŠMT (2001). Bílá kniha: Národni program rozvoje vzděláváni v České republice. Dostupné z www.msmt.cz/dokumenty/bila-kniha

Píšová, M., et al. (2011). Teorie a výzkum expertnosti v učitelské profesi. Brno: Masarykova univerzita. Podkladový materiál pro tvorbu standardu kvality profese učitele (2010). Učitelské noviny, 12. Dostupné z www.ucitelskenoviny.cz/?archiv\&clanek=3497

Pollard, A. (2001). Reflective teaching. London: Cassel.

Rýdl, K. (2014). Vývoj standardizace profese učitele v České republice - nekonečný př́běh? Orbis Scholae, 8(3), 9-21.

Scio, kolektiv autorů (2013). Motivace, priority a kvalita uchazečù o VŠ. Dostupné na www. scio.cz/download/analyzy/souhrn_poznatku_Vektor_uchazeci.pdf

Shulman, L. S. (1987). Knowledge and teaching: Foundations of the new reform. Harvard Educational Review, 57, 1-22.

Simonová, J., \& J. Straková, J. (2005). Vymezeni hlavnich problémů obrožujicich realizaci kurikulárni reformy. Praha: SKAV.

Spilková, V. (2010). Evropské př́stupy k pojetí kvality učitele optikou formálních dokumentů. Pedagogika, 60(3-4), 265-275.

Spilková, V., et al. (2004). Současné promèny vzdělávání učiteli̊. Brno: Paido.

Spilková, V., \& Hejlová, H. (Eds.) (2010). Príprava učitelů pro primárni a preprimárni vzdèláváni v Česku a na Slovensku. Vývoj po roce 1989 a perspektivy. Praha: Pedagogická fakulta UK.

Spilková, V., \& Tomková, A., et al. (2010). Kvalita učitele a profesní standard. Praha: Univerzita Karlova.

Spilková, V., \& Vašutová, J. (2008). Učitelská profese v měnicich se požadavcich na vzdělávání. Praha: Pedagogická fakulta UK.

Spilková, V., \& Wildová, R. (2014). Potřebujeme kvalitní, nebo kvalifikované učitele? Pedagogická orientace, 24(3), 423-432.

Straková, J., Spilková, V., et al. (2013). Názory učitelů na potřebu změn ve školním vzdělávání. Orbis scholae, 7(1), 79-100.

Straková, J., Spilková, V., et al. (2014) Profesní přesvědčení učitelů základních škol a studentů fakult připravujících budoucí učitele. Pedagogika, 64(1), 34-65.

Štech, S. (2011). Boloňský proces: nutný proces adaptace, nebo trojský kůň neoliberálních změn vysokoškolského vzdělávání? Aula, 19(1), 25-30.

Štech, S. (2013). Když je kurikulární reforma evidence less. Pedagogická orientace, 23(5), 615-633.

Tomková, A., et al. (2012). Rámec profesnich kvalit učitele. Hodnotici a sebehodnoticí arch. Praha: Národní ústav pro vzdělávání, školské poradenské zařízení a zařízení pro další vzdělávání pedagogických pracovníků.

Urbánek, P. (2005). Vybrané problémy učitelské profese. Aktuální analýza. Technická univerzita v Liberci. 
Urbánek, P. (2006). Změny ve strukturaci učitelského studia v kontextu současné školní kurikulární reformy. In Kompetence učitele na pozadí současné kurikulární reformy (s. 82-85). Univerzita Hradec Králové.

Urbánek, P. (2013). Vzdělávání učitelů v České republice (po Česku): Riziko deprofesionalizace. In J. Ferencová \& I. Ištván (Eds.), Križovatky na cestách $k$ učitelstvu. Prešov: FHPV PU a Škola plus.

Vašutová, J. (2004). Profese učitele v českém vzdělávacím kontextu. Brno: Paido.

Walterová, E. (Ed.) (2004). Úloha školy v rozvoji vzdělanosti. Brno: Paido.

Závérečná zpráva podskupin Národni ekonomické rady vlády pro konkurenceschopnost a podporu podnikání. Kapitola III. - Vzdělanost (2011). Dostupné z www.vlada.cz/assets/media-centrum/aktualne/NERV_kap03.pdf

prof. PhDr. Vladimira Spilková, CSc.

Univerzita Karlova, Pedagogická fakulta; e-mail: vladimira.spilkova@pedf.cuni.cz

SPILKOVÁ, V. Approaches to Czech Education Policy since 1989: The deprofessionalisation of the teaching profession and teacher training?

The article is devoted to critical reflection on the development of the approaches of Czech education policy to the teaching profession and teacher training after 1989. It offers an analysis of relevant documents of education policy, draft laws and actual interventions in this sector by decision-makers in the last 25 years. We foreground milestones in the trends and key problems - the professionalisation of the teaching profession and support for this from the side of education policy vs. deprofessionalisation, the professional standard as a set of key professional competences that are the prerequisite for teachers to be able to carry out their vocation with excellence in a situation of changing demands on school education, the career system as a means to support the professional growth of teachers, approaches to the quality of teacher training, the degree of liberalism of education policy in the field of teacher training in the context of major curricular reforms (academic freedom on the one hand and the state's responsibility for the quality of education and hence also the quality of teachers on the other hand), the definition of framework requirements for teacher training from the side of the state, the realistic possibilities and limits of the Accreditation Commission of the CR to influence the quality of education at faculties training future teachers.

Keywords: education policy, changes in the profession in the context of changes in school education, professionalisation and deprofessionalisation of teachers, professional standard, quality of teacher training, faculties training teachers, accreditation commission. 